\title{
Social and ethnic segregation in the Paris metropolitan area at the beginning of the 21 st century
}

\begin{abstract}
Although the socio-spatial aspect of cities in the globalisation era has gained a new dimension, it cannot be explained by the globalisation process alone. The article presents the problem of social and ethnic segregation in Île-de-France between 1999 and 2009. Socio-economic and demographic data are used to measure indices of segregation and the description of characteristic chosen districts to show its spatial inertia. The analysis revealed a higher degree of social segregation in the entire Paris metropolitan region than in the city of Paris itself. The upper class is the most segregated group, followed by foreigners, immigrants and the lower class. The pattern emphasises the important role of autosegregation factors and functions. It is observed that a constant division into homogenous parts exists in the prestigious and affluent western districts and the impoverished immigrant north-eastern districts. Socio-spatial tendencies reveal the growing importance of the upper class.
\end{abstract}

Keywords

Social segregation $\cdot$ spatial polarisation $\cdot$ autosegregation

- segregation indices • Paris • Île-de-France

(c) University of Warsaw - Faculty of Geography and Regional Studies

\author{
Anna Grzegorczyk \\ Faculty of Geography and Regional Studies \\ University of Warsaw \\ e-mail: anna.torbicz@uw.edu.pl \\ Received: 11 October 2012 \\ Accepted: 5 June 2013
}

\section{Introduction}

The spatial aspect of social structure, which was always recognisable in cities, gained a new dimension in the globalisation era. However, spatial polarisation and fragmentisation seem to be more complex and difficult to explain only by means of the globalisation process. Enclaves of affluence, deprivation and - more often - also of ethnicity, are dispersed in cities. They are characterised by greater extremes and are more isolated, both literally and figuratively. Among the interrelated physical and mental barriers of enclaves, the latter are less likely to be surmountable.

The quantitative analysis of social and ethnic segregation in France is rare in contrast to political debates on the socioeconomic gap and the ghettoization of the country with the increasing ethnicization of social issues. Therefore, the aim of the article is to present the social and ethnic segregation in the Paris metropolitan area at the turn of the $21^{\text {st }}$ Century and to analyse the segregation trends. The existing tendencies of socio-spatial development of the Paris metropolitan area are explained using common connotations for particular chosen districts.

\section{Methodology}

The methodology of segregation studies is characterised by four dimensions: (1) the population categories under study, (2) the geographic zone, (3) the geographical units which comprise the zone analysed, and (4) the segregation measure (Safi 2009). In France, social segregation was analysed using socio-professional categories (see more about their advantages and disadvantages in Préteceille 2006), household structure and demographic composition (Rhein 1998, Lajoie 1998), as well as academic achievements and income level (Maurin 2004). Meanwhile, in an ethnic segregation analysis, the majority group, French by birth, was compared to the minority group: naturalised French and foreigners (Safi 2009, more about the reasons for the lack of precise immigration data: Grzegorczyk 2012). Secondly, for the geographic zone, French metropolitan areas - aires urbaines, which are the principal urban areas - were used (see more about the advantages and disadvantages in Préteceille 2006 and Guérois \& Paulus 2002), as well as a more compact area i.e. an inner agglomeration (la Petite Couronne) (Rhein 1998). Thirdly, communes constituted the geographical units, although the disadvantages of this scale should be kept in mind, e.g. the heterogeneous character of districts in terms of demographic structure or infrastructure development (see more about their advantages and disadvantages and comparison to IRIS zones in Préteceille 2006 and Safi 2009). In this article, the unemployment rate and socio-professional categories per commune are used to measure social segregation, and rate of immigrants and foreigners per commune to measure ethnic segregation: in the whole region of Île-de-France, being the most similar to the Paris metropolitan area, and in the city of Paris itself, in 1999 and 2009.

Finally comes the last and most complicated dimension; there are many interrelated and complementary measures of segregation and the segregation phenomenon is diverse, hence the need to use different indicators of segregation (see Appendix). They can be classified into the following dimensions:

${ }^{1}$ Although more precise data are recommended in the literature, currently they are not available 
(1) evenness, (2) exposure, (3) concentration, (4) centralisation and (5) clustering ${ }^{2}$ (Massey \& Denton 1988). The first and most commonly used dimension, the differential distribution of social groups among area units in a city, is calculated in the article by the dissimilarity index (ID). The second dimension - exposure measures the degree of potential contact, i.e. the degree to which particular groups share a common residential area, indicating the probability of contact between them: that one person will meet another person from another group (interaction index ${ }_{x} P_{y}$ ) or from the same group (isolation index ${ }_{x} P_{x}$ ). In contrast to the dissimilarity index, which is rather an abstract one, the exposure indices measure level of segregation experienced. The third dimension, concentration - characterised by index $D E L$, which is calculated in the paper - refers to the amount of space occupied by a particular group, indicating residential discrimination if the group is restricted to a small share of an urban area. A fifth index was added to the four presented above as a measure that corresponds strictly to the geographical dimension - the modified localisation index $L Q_{p}$, which measures the concentration of a particular group in an area unit, e.g. in particular communes (Węclawowicz 2007)

Firstly, the literature on the segregation process, both social and ethnic, is presented in the article. In the second part, the particularity of the Paris metropolitan area is described. In the third part, a quantitative analysis is given, using the dissimilarity, interaction, isolation, concentration and modified localisation indices for socio-economic and demographic data ${ }^{3}$. The tendencies revealed are enriched with a description of particularly characteristic districts of Paris and photographic examples of the chosen districts: affluent (Neuilly-sur-Seine and Sceaux), middle class (XIII arrondissement) and lower status, and with an ethnic connotation (Belleville and St. Denis).

\section{Background on social and ethnic segregation}

In all definitions, social and spatial aspects constitute the segregation concept. G. Węclawowicz (2007) defines segregation as spatial inequalities being the consequence of social diversity. However, this relationship is not bidirectional, therefore reduction of segregation does not imply a society's homogeneity. According to G. Lajoie (1998), the concept is polysemic and may be applied as urban, social, residential or scholarly segregation; it may refer to either a state or a process and can have moral connotations by indicating socio-spatial injustice. Methodologically, confusion can also appear over study and time scale, and the threshold distinguishing diversity from segregation. B. Jałowiecki (2010) distinguishes segregation from aggregation i.e. the voluntary decision of individuals to live among the same social group, which is called autosegregation by E. Préteceille (2006) or congregation by P. Knox and S. Pinch (2000). While segregation is associated with poverty and may cause negative effects on a segregated group, autosegregation may improve social capital, causing some kind of social mobility. However, the distinction between the two issues might be vague in practice due to their overlapping causes. Both phenomena are complex and result from economic, social, political and cultural processes, as shown by e.g. B. Jałowiecki (2010):

(1) the real estate market and housing prices, as people indicate their social adhesion by their place of residence. $B$. Jałowiecki (2010), following J. Rex, distinguished five housing classes: owners of accommodation in the best districts, owners of similar accommodation but with mortgages, owners

${ }^{2}$ Centralisation, i.e. the degree to which a group is spatially located near the city centre, and clustering, i.e. the degree to which units inhabited by minority groups adjoin to one another, are not calculated in the article

${ }^{3}$ The outcomes concerning the farmers' group are not taken into account in the analysis due to their low share in the whole area's population. of accommodation with mortgages in worse districts, tenants privately renting flats and council housing occupants. Social conflicts occur over access to the real estate market (credits and social housing) and immigrants are the most disadvantaged group, so are forced to rent degraded and overpopulated flats in the transition zone. Price is also an important factor in the suburbs and is influenced by the commune brand and infrastructure investments;

(2) better school locations, as schools are now considered to be the main factor in a successful career and seem to be an important factor for the residential location of the better-off, too;

(3) family strategies, which are shaped by residence, work and service location, and family situation. The population's inclination to mobility and its availability are linked to this factor;

(4) a wish to live among the same social group - an important factor among the city's elite as well as among the lower status inhabitants and immigrants.

The segregation phenomenon may be considered as negative because it leads to social isolation and exclusion from common goods and may cause crime, social pathology, deprivation and the creation of an underclass (Węclawowicz 2007). Furthermore, it inhibits social vertical mobility to higher classes, and may result in discrimination against the stranger in general and particularly against the representatives of different races, as well as ethnic, cultural and social groups. It is calculated that in France there are over 600 residences inhabited by disadvantaged populations, where a high risk of social pathology is present. These are mainly large housing estates (mostly HLM) in the suburbs (Jałowiecki 2010). As a consequence, social and urban policies are focused on such areas. In general, two types of countermeasures can be distinguished ((Węclawowicz 2007):

(1) permanent mixing of members of different social classes and ethnic origins in a common place to avoid homogenisation this policy may mainly appear in districts governed by left-wing authorities and is possible in social housing neighbourhoods:

(2) policy focused on problem areas, e.g. related to financial aid, vocational training, service development, incentives for enterprises etc.

It seems that autosegregation can also be considered negative. Autosegregation may create separation of the elite from social issues and unwillingness to find solutions to them, i.e. contesting redistribution measures of public policy (progressive tax or social policy) and the solidarity idea (questioning of social housing) (Préteceille 2006). However, the term "autosegregation" does not need to have such a negative connotation. It may also refer to the freedom to choose one's place of residence in a free market economy and willingness to live among the same socioethnic group to maintain common values. Hence, autosegregation has four functions (Knox \& Pinch 2000): (1) defence - the most common one, being a consequence of the antagonistic dominant group approach, (2) mutual support - economic and social support for representatives from the same group, (3) cultural preservation - conservation and promotion of one's own culture, (4) "attack" facilitation - creation of spaces of resistance for voting campaigns, for example.

The segregation phenomenon is physically visible in homogenous and isolated areas in cities. As M. Castells (1998, p. 164-165) describes, this phenomenon consists of "multiple black holes of social exclusion throughout the planet" which are "present in literally every country, and every city, in this new geography of social exclusion. It is formed of American innercity ghettoes, Spanish enclaves of mass youth unemployment, French banlieues housing North Africans, Japanese Yoseba quarters and Asian mega-cities' shanty towns". All such areas inhabited by ethnic minorities can be categorised into: (1) a ghetto, inhabited by a minority group in a polarised society, where 
the people's place of residence is forced by the organisation system of the society (Węclawowicz 2007). This term was used to refer to peripheral estates in France by L. Wacquant and M. Dikeç (Daniels et al. 2008). However, É. Maurin (2004) uses the term to describe all French enclaves of the affluent, the upper middle class, the lower middle class, the working class, the unemployed and finally, immigrants; (2) an ethnic enclave - inhabited by a minority group in a pluralistic society (Węclawowicz 2007).

Other categories of isolated and homogenous areas distinguished by their socio-economic status are to one extreme: (3) slums and (4) squatter settlements or shanty towns, while to the other extreme there are (5) gated communities. According to E. J. M. G. Blakely and M. G. Snyder (1997) they can be categorised into the following types: lifestyle communities resulting from common interests, prestigious communities indicating social differentiation from others, and security zone communities, which are a response to a deteriorating sense of safety. The literature on polarization and segregation is much more focused on disadvantaged populations and deprived areas than on the isolation of the upper-class (Préteceille 2006).

The development of minority enclaves was particularly studied by the Chicago School - there is an indication of the existence of a spatial assimilation of immigrants, who integrate with a host society by residential distribution and culturally tend to resemble the majority population (Knox \& Pinch 2000, Safi 2009). This process is hypothetically natural, inevitable and irreversible. Two variables influence the process: (1) the duration of immigrants' stay or the duration and permanence of migration influx and (2) the socio-economic achievement of immigrants or their social mobility. So theoretically, with time, immigrants convert their income into spatial outcome, causing desegregation. In reality, some groups of immigrants do not follow this pattern as in, for example, the situation of Afro-Americans in the United States, which was called the "racial frontier" by N. A. Denton (Safi 2009). Neither does the process does not seem to be natural; in the Unites States ethnic segregation increased in the $20^{\text {th }}$ Century as a result of discrimination policies, both official and unofficial, and independently from market forces, which theoretically could introduce ethnic distribution. Moreover, the Chicago School concept does not take autosegregation and formation of ethnic enclaves into consideration. Thus, although immigrants could afford better locations in a majority group neighbourhood, they choose an ethnic environment, which, contrary to the theory, is a durable residential strategy for immigrants.

Research on the segregation problem takes different approaches in different geographic contexts: those of Europe and America are presented in this paragraph. In Europe there is mainly social and ethnic segregation, while in the United States, racial segregation is the main issue. Additionally, in the academic literature, a discussion can be observed on whether segregation is more advanced in American or European cities. Contrary to the more common understanding of this problem, B. Jałowiecki (2010) reveals that, according to E. Préteceille, sociospatial segregation in Western European cities (when measured by the residential concentration of blue-collar workers) is higher than in the United States: the lowest concentration, in Paris, is followed by New York, then London and finally Madrid. M. Safi (2009) indicates that the lower segregation levels of immigrants in France compared to the United States may originate from a different division into geographical units and from the incorporation of second generation immigrants into American studies, which in the French case is impossible due to a lack of data. Therefore, the considered segregation outcomes are difficult to compare and may be much higher in France. B. Jałowiecki (2010) additionally argues that the pattern of prestigious European and deprived American city centres, although generally true, is more complex; enclaves of the better-off and the impoverished are scattered across metropolitan areas. Finally, European cities are characterised by five times greater stability of the socio-spatial city structure as a consequence of the inhabitants' lower spatial mobility and a greater attachment of the better-off to the city centre. Nevertheless, the mobility of the upper-class population may increase with the emergence of a metropolitan class ${ }^{4}$ (Jałowiecki 2010).

\section{Social segregation in France and Paris}

The highest social segregation between the 1980s and the 1990s in the twenty studied French urban areas appeared among the upper class (particularly executives and academics), followed by the lower class (particularly the economically inactive and, to a lesser extent, among blue-collar workers), and its levels increased over the time period (Lajoie 1998). The middle class presented much higher spatial heterogeneity. Two exceptions from the pattern were revealed: Nice, where the segregation level increased among all of the socio-professional categories, and Nantes, where the indicator decreased. Geographically, the highest social segregation was observed in the cities of HauteNormandie and the lowest in Nord-Pas-de-Calais and along the southern Mediterranean strip, where cities were smaller; there were less populated agglomerations inhabited by a more homogeneous population. The socio-economic gap increased additionally between core areas and peripheries of the areas under study. The pattern of social segregation was confirmed by the analysis of other demographic and socio-economic indicators: the unemployment rate, the share of single parent families and large families, the share of the foreign population and the elderly.

In Paris, the upper class is also the most segregated, followed by the lower class and immigrants, and the socio-spatial gap between these two most isolated groups is deepening (Préteceille 2006). This general pattern is diversified when analysing particular socio-professional groups. On the one hand, the metropolitan class is the most concentrated and its spatial concentration is increasing, while the upper class working in the public sector and academics (along with other senior intellectual workers) remain less isolated from the rest of society. On the other hand, the more impoverished groups, together with ethnic minorities, live in high segregation. The middle class comprises $45 \%$ of the total Paris population, making up a significant part of the society; generally it does not separate itself from impoverished groups and lives in heterogeneous districts (Préteceille 2006). Thus, as E. Préteceille (2006) states, the global-dual city hypothesis of S. Sassen (1991) is not supported completely. Exceptions to the behaviour of the middle class can be seen in only two cases: among entrepreneurs and those living in the most deprived districts. Both of these groups abandon their prior locations for the mixed districts. Additionally, contrary to typical city structure, the suburbs remain heterogeneous. The described pattern is prone to changes due to unemployment and an increase in employment insecurity (Préteceille 2006). The extremes existing in the Parisian society together with their often violent consequences (e.g. the banlieus riots of October / November 2005) originated according to K. Mitchell (2011) from: (1) the character of city economy transformed by Baron Haussmann's regeneration programmes, with the prominent role of financial institutions, centralised financial power shared among a few families, the friendship effect linked to ENA ${ }^{5}$ and finally the global city status; (2) city structure - the city centre is surrounded by industrial ceintures

${ }^{4}$ Population with professional occupations in transnational financial institutions ${ }^{5}$ École nationale d'administration - the most prestigious French school, founded in 1945 by Charles de Gaulle, where access is restricted to those finishing special and paid preparation classes, and which guarantees high positions / posts in the state. 
rouges, stigmatised banlieus with negative ethnic and religious connotations; (3) urban policy culture - the Republican model of assimilation and the authoritarian law-and-order model of the centre-right government.

\section{Ethnic segregation in France and Paris}

In 2007, there were 5.1 million immigrants in France living mainly in three regions - Île-de-France $(40 \%$ of all immigrants, 2 million people), Rhône-Alpes and Provence-Alpes-Côtes d'Azur - and originating mainly from Maghreb, Sub-Saharan Africa and Turkey (INSEE 2011). Their geographical distribution over the last three decades has changed neither on a national scale (with their concentration in the east, in Île-de-France and in the south-east), nor on a communal scale (Safi 2009). Paris, Lyon, Lille and Strasbourg are generally the most segregated French metropolitan areas, from the eight largest areas analysed (Safi 2009). In 1999, the dissimilarity index for all immigrants in French urban areas exceeding 50,000 people accounted for $24 \%$, which indicates a moderate concentration and its slight decrease. Nevertheless, the particular immigrant groups were segregated differently (Pan Ké Shon 2011). The lowest, and furthermore decreasing, segregation levels were for Spanish and Italians, while an increasing trend was seen among other WestEuropean immigrants (Safi 2009). The highest values were among the Moroccan, Tunisian and Algerian populations, all over $40 \%$, which slightly increased after 1990 . The very high concentration of the South-East Asian population decreased (Safi 2009). The highest segregation index referred to the Turks in Marseille $(I D=0,51)$.

In Île-de-France, immigrants are concentrated mainly in Paris and the Seine-Saint-Denis department (over 20\% of the population), and in the Val-de-Marne department; in these districts both their share of the population and level of segregation increased the most (Pan Ké Shon 2011). The segregation indices in 1999 of all immigrants from Arab and Sub-Saharan Africa approximated $30 \%$ and for Turks reached almost $50 \%$ (Pan Ké Shon 2011, Safi 2009). Segregation indices for South-East Asian immigrants and also for Maghrebians, Spanish, Italians and Portuguese decreased in Île-de-France between 1990 and 1999 , decreasing only for Tunisians in the Paris agglomeration (Safi 2009). African immigrants were also the most clustered and excluded from city life while Asians, although highly segregated, inhabited areas distant from one another, which indicates a tendency to build an immigrant network rather than to support exclusion (Safi 2009). An increase in African population regrouping was observed in the analysed thirty year period (1968-1999). In general, segregation appeared to be more closely linked to immigrants socio-economic situation rather than to their migration paths.

Although immigrants from Sub-Saharan Africa, Maghreb and Turkey (further called AMT) did not constitute a majority in any of the communes in the region, they were highly present in insecure districts (with the highest unemployment levels). To illustrate this, in 2008 , in $10 \%$ of the worst such districts in France, $42 \%$ of the population were immigrants from AMT and only $10 \%$ came from the French majority population (Pan Ké Shon 2011). Immigrants children were less present in such zones. In ZUS ${ }^{6}$, immigrants and their children from AMT constituted $35 \%$ of the population, other immigrants $15 \%$ and the majority French population $46 \%$. The study of Marseille revealed that the most deprived ZUS concentrated the highest share of foreigners (around 20\%)

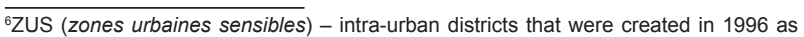
priority zones for urban, economic and social policies. The zones are characterised by large housing estates and degraded buildings as well as low employment rates. The policy focus in these zones is placed on ameliorating employment prospects. There are 2 types of zones: zones de redynamisation urbaine (ZRU) and zones franches urbaines (ZFU). and most of the ZUS were inhabited at over $10 \%$ by foreigners, mainly in the northern part of the city (Grzegorczyk 2012). Thus, although immigrants and their children are segregated and overrepresented in districts with a high concentration of poverty, the second generation lives in slightly better conditions and more often among the French majority population; $72 \%$ of immigrants from AMT and $76 \%$ of immigrants' children live outside ZUS (Pan Ké Shon 2011). Therefore, there is an indication of a tendency for a certain levels of residential integration. P.-E. Bidoux and P. Virot (2011) give similar evidence for Paris, where the situation of immigrants in the housing market was ameliorated. The majority of Paris immigrants rent their accommodation, while only $20 \%$ of them are owners. However, it is access to council housing estates (HLM - habitation à loyer modéré) that has improved the situation substantially $-20 \%$ of immigrants live in such estates ( $25 \%$ of non-EU immigrants), while in 1982 they constituted only $8 \%$ of social park inhabitants. Renting a flat is still the most common practice despite high renting prices. Accommodation overcrowding remains a real problem ${ }^{7}$. This is the case of $27 \%$ of immigrant households in Île-de-France, $33 \%$ in Seine-SaintDenis and $26 \%$ in Paris. The same share for non-immigrants accounts for $7 \%$.

An analysis of perceived discrimination and discrimination in the labour market, measured by unemployment rate and access to better-paid posts, shows similar trends to those of immigrant accommodation and immigrant segregation (Bidoux \& Virot 2011, Safi 2009). Additionally, some degree of immigrant social exclusion and discrimination was revealed by a study of the political participation of non-European-origin migrants (Maxwell 2010). Hence, social exclusion of immigrants is a complex issue. In the article, only one of these aspects is analysed.

\section{Analysis}

The highest segregation is consistently among executives and senior intellectual workers, followed by blue-collar workers, foreigners and immigrants ${ }^{8}$, and the unemployed in Île-de-France (tab. 1). This pattern reveals the autosegregation phenomenon particularly present among the present-day Paris "great bourgeoisie". Their common place of residence and similar lifestyle are accompanied by the will to isolate themselves from strangers and their problems, by such methods as rejecting HLM housing in the upper-class districts and contesting social urban policy in general (Prétecaille 2006). Following B. Jałowiecki (2010) it can be stated here that it is an accumulation of affluence rather than poverty that makes the Paris region socially polarised. A slightly different pattern, with fluctuations between 1999 and 2009 , is seen in the city of Paris, where blue-collar workers, craftsmen, shopkeepers, managers and the unemployed are followed by executives and senior intellectuals (tab. 2). In Paris, the dissimilarity indices remain at a much lower level than in the entire Île-de-France region, which supports earlier conclusions (Safi 2009). These are the contrasts of the Paris suburbs that make the whole region more diversified but also polarised. Industrial functions along with poorer housing estates were expelled to the northern city districts, and to a greater extent outside the city, in the XIX Century (Baron Haussmann's regeneration programs). Intermediary professions are constantly the least segregated on both scales, which also confirms previous analyses. Their

\footnotetext{
${ }^{7}$ According to the INSEE definition, overcrowding refers to the insufficiency of number of rooms according to regulations and to a flat size of below $18 \mathrm{~m}^{2}$ per person.

${ }^{8} \mathrm{An}$ "immigrant" is defined as a foreign person born abroad and living in France, whose status is permanent and does not depend on a possible citizenship acquisition. Hence, it is the country of origin and not the nationality that defines an immigrant. A "foreigner" is defined as a person living in France and not having French citizenship. After acquiring French citizenship they become French by acquisition (by naturalisation, marriage, declaration) (INSEE 2012).
} 
representatives live in heterogeneous districts, they often descend from the lower-classes and are more open to their problems (Prétecaille 2006). These tendencies, measured between 1999 and 2009 , revealed themselves to be more complex; segregation of executives and senior intellectuals decreased throughout the period whereas segregation of employees increased in both îlede-France and Paris. The first tendency can be explained by the decreasing segregation of senior intellectual workers despite the increase in the segregation of executives, which was indicated in the literature yet could not be proved in this analysis due to a lack of data (Prétecaille 2006). The second tendency can be explained by the general greater concentration of the lower-class population, observed in the Paris region, due to their withdrawal from heterogeneous districts and the urban regeneration schemes introduced there, for example. This process is described later in the article. The other groups saw contrary outcomes in both areas. In île-de-France, segregation of blue-collar workers increased between 1999 and 2009, while segregation of the unemployed and intermediary professionals remained stable. In Paris, segregation increased among craftsmen, shopkeepers and managers, while the greatest decrease was among the unemployed and to a lesser extent among blue-collar workers. Dissimilarity indices measured for immigrants were slightly lower in comparison to the same indices for 1999, which may indicate some degree of their spatial integration (Safi 2009).

The exposure indices appeared to be correlated with particular groups' shares in the metropolitan population, which was indicated as a limitation of the method by D. S. Massey and N. A. Denton (1988). The highest interaction probability was between craftsmen, shopkeepers, managers, the unemployed, foreigners and blue-collar workers, and the rest of the population, while the highest isolation was found between executives, senior intellectuals, employees and intermediary professions, and the rest of the population (tab. 1). A similar pattern can be observed in Île-de-France and Paris (tab. 2). Between 1999 and 2009 the greatest change in île-de-France was seen among executives and senior intellectual workers, and blue-collar workers. For the former group the interaction probability decreased and isolation increased, while for the latter the interaction probability increased and isolation decreased. In Paris, the pattern is similar; however, a significant increase in the isolation of craftsmen, shopkeepers and managers is noticed. The highest isolation, seen in the executives and senior intellectual workers group, together with their highest dissimilarity index, could indicate the strongest segregation in comparison to other groups. However, these conclusions are ambiguous due to the mentioned influence of the share of particular groups in the population on the level of the indices; the values and tendencies of data seem to be linked.

The concentration measured by the delta index is the highest for foreigners, immigrants, the unemployed, and executives and senior intellectual workers, which indicates that their greatest proportion should be displaced to create an even distribution in Île-de-France (tab. 1). That is, they inhabit a disproportionately small area in comparison to their share in the population, revealing their spatial segregation. This index proves the existence of homogeneous enclaves - most distinctively enclaves of immigrants but also enclaves of poverty and affluence are seen, where a specific social or ethnic group is concentrated in a small area. Their spatial aspect is described in the following paragraphs. The most evenly distributed groups are craftsmen, shopkeepers, managers and blue-collar workers. In the city of Paris, blue-collar workers and the unemployed are the most concentrated. However, the outcomes are significantly lower than in Île-de-France, similar to the pattern presented by the index of dissimilarity already described. The changes in the period under analysis are not significant.
The localisation index shows the spatial aspect of the patterns already described. It gained the highest values for executives and senior intellectual workers, craftsmen, shopkeepers and managers, blue-collar workers and foreigners in Île-de-France and with some rank changes also in Paris. However, in this case, the city's index values were much lower than in the whole metropolitan area. The lowest $L Q_{p}$ values were among the unemployed in Île-de-France and among intermediary professions in Paris. Communes with the highest $L Q$ values were the most clustered together for executives and senior intellectual workers and immigrants, and foreigners. Some clustering was also noticed among the unemployed and workers. These outcomes prove that the location of particular enclaves of immigrants, of affluence and also of poverty, is not coincidental. The unemployed are concentrated in the northern Île-de-France region, mainly close to the city, and in the north-eastern arrondisements. A very similar spatial pattern was revealed among immigrants and foreigners. Blue-collar workers were mainly localised in the further southeastern communes of the region, but also a few foci can be distinguished in the north of the metropolitan area. Employees were concentrated in similar regions; however, they were much more dispersed mainly in the north of the area. Executives were highly clustered in the west and also in the south-western part of the city, communes with the highest $L Q_{p}$ values creating a compact area. Groups of craftsmen, shopkeepers and managers, and of intermediary professions, were dispersed around the Paris metropolitan region. High values of $L Q_{p}$ as well as the proximity of particular communes of executives and senior intellectual workers, blue-collar workers and foreigners indicate their high clustering, not only in particular communes but also in a distinct region of the metropolitan area. On the other hand, although the craftsmen, shopkeepers and managers groups are localised in particular communes, they do not create a compact area. The pattern described presents some spatial inertia, where the character of particular districts remains unchanged (Claval 1981)

The Paris upper-class follows tropism to the western urban area districts with high precision, even though they could afford to live anywhere in the city. These areas are expensive due to the presence of the Paris bourgeoisie, yet it is not the high prices that attract the bourgeoisie (Jałowiecki 2010) - it is also the French history and tradition that influence this area's prestigious character. These "beautiful districts" of Paris - les beaux quartiers - are mainly the VIIth and XVIth arrondisements and their neighbourhoods, inhabited by ENA graduates and Académie française members; exclusive club members live additionally in the south-western part of the XVIIth district, in the VIIIth district and in the $\mathrm{XV}$ th district, which is currently inhabited by the middle class (Jałowiecki 2010 following Pinçon \& Pinçon-Charlot 1996). In the XVth and XVIth arrondisements there are a few gated community areas: from single streets to the most spacious gated villa district, Villa Montmorency. This area is inhabited by French billionaires and executives, as well as politicians and artists. The villas are valued at over 10 million euros (up to 40 million euros), some of them 600 sq. metres and with a 1 ha garden (La Cité interdite 2008). Other prestigious districts are located in the western suburbs, and Neuilly is the most famous example, located in an attractive area, near Bois de Boulogne (fig.1A). Despite the $\mathrm{SRU}^{9}$ law introduced in 2000 , imposing a minimum of $20 \%$ social housing for each commune, in Neuilly, there are around $2 \%$ of HLM. Being more expensive and of better quality, they are inhabited by the more affluent. The commune pays a penalty fee for violating the SRU law, which increases local taxes. Since the 19th Century the area has been inhabited by the aristocracy and the bourgeoisie and, having the highest housing ${ }^{9} \mathrm{SRU}$ - Solidarité et renouvellement urbain 
Table 1. Indices in Île-de-France

\begin{tabular}{|c|c|c|c|c|c|c|c|c|c|c|c|c|c|c|}
\hline \multirow{2}{*}{ indicator } & \multicolumn{2}{|c|}{$\begin{array}{l}\text { share of the } \\
\text { population }\end{array}$} & \multicolumn{3}{|c|}{ eveness } & \multicolumn{6}{|c|}{ exposure } & \multicolumn{3}{|c|}{ concentration } \\
\hline & $\begin{array}{c}\% \\
1999\end{array}$ & $\begin{array}{c}\% \\
2009\end{array}$ & $\begin{array}{c}\text { ID } \\
1999\end{array}$ & $\begin{array}{c}\text { ID } \\
2009\end{array}$ & $\begin{array}{c}\% \\
\text { change }\end{array}$ & $\begin{array}{l}\mathrm{aPb} \\
1999\end{array}$ & $\begin{array}{l}\mathrm{aPb} \\
2009\end{array}$ & $\begin{array}{c}\% \\
\text { change }\end{array}$ & $\begin{array}{c}\mathrm{aPa} \\
1999\end{array}$ & $\begin{array}{c}\mathrm{aPa} \\
2009\end{array}$ & $\begin{array}{c}\% \\
\text { change }\end{array}$ & $\begin{array}{l}\text { DEL } \\
1999\end{array}$ & $\begin{array}{l}\text { DEL } \\
2009\end{array}$ & $\begin{array}{c}\% \\
\text { change }\end{array}$ \\
\hline $\begin{array}{l}\text { unemployment } \\
\text { rate }\end{array}$ & 11,6 & 10,9 & 0,127 & 0,127 & 0 & 0,871 & 0,879 & 1 & 0,129 & 0,121 & -6 & 0,742 & 0,743 & 0 \\
\hline farmers & 0,1 & 0,1 & 0,727 & 0,646 & -11 & 0,964 & 0,970 & 1 & 0,036 & 0,030 & -17 & 0,372 & 0,458 & 23 \\
\hline $\begin{array}{l}\text { craftsmen, } \\
\text { shopkeepers, } \\
\text { managers }\end{array}$ & 5,1 & 4,4 & 0,113 & 0,097 & -15 & 0,944 & 0,952 & 1 & 0,056 & 0,048 & -15 & 0,674 & 0,671 & 0 \\
\hline $\begin{array}{c}\text { executives, } \\
\text { senior intellectual } \\
\text { workers }\end{array}$ & 21,0 & 26,1 & 0,243 & 0,229 & -6 & 0,728 & 0,671 & -8 & 0,272 & 0,329 & 21 & 0,740 & 0,738 & 0 \\
\hline $\begin{array}{c}\text { intermediary } \\
\text { professions } \\
\text { (administrative } \\
\text { workers, } \\
\text { technicians, } \\
\text { associate } \\
\text { professionals, } \\
\text { clerks and office } \\
\text { assistants, etc.) }\end{array}$ & 24,6 & 25,9 & 0,058 & 0,058 & 1 & 0,748 & 0,736 & -2 & 0,252 & 0,264 & 5 & 0,689 & 0,682 & -1 \\
\hline employees & 29,8 & 27,5 & 0,078 & 0,103 & 32 & 0,692 & 0,710 & 3 & 0,308 & 0,290 & -6 & 0,708 & 0,702 & -1 \\
\hline $\begin{array}{l}\text { blue-collar } \\
\text { workers }\end{array}$ & 18,0 & 14,9 & 0,195 & 0,212 & 9 & 0,783 & 0,813 & 4 & 0,217 & 0,187 & -14 & 0,691 & 0,685 & -1 \\
\hline immigrants & n.a. & 8,3 & n.a. & 0,171 & & n.a. & 0,792 & & n.a. & 0,208 & & n.a. & 0,779 & \\
\hline foreigners & n.a. & 5,6 & n.a. & 0,195 & & n.a. & 0,844 & & n.a. & 0,156 & & n.a. & 0,785 & \\
\hline
\end{tabular}

Source: Self-elaborated after : INSEE 2012

Table 2. Indices in Paris

\begin{tabular}{|c|c|c|c|c|c|c|c|c|c|c|c|c|c|c|}
\hline \multirow{2}{*}{ indicator } & \multicolumn{2}{|c|}{$\begin{array}{l}\text { share of the } \\
\text { population }\end{array}$} & \multicolumn{3}{|c|}{ eveness } & \multicolumn{6}{|c|}{ exposure } & \multicolumn{3}{|c|}{ concentration } \\
\hline & $\begin{array}{c}\% \\
1999\end{array}$ & $\begin{array}{c}\% \\
2009\end{array}$ & $\begin{array}{c}\text { ID } \\
1999\end{array}$ & $\begin{array}{c}\text { ID } \\
2009\end{array}$ & $\begin{array}{c}\% \\
\text { change }\end{array}$ & $\begin{array}{l}\mathrm{aPb} \\
1999\end{array}$ & $\begin{array}{l}\mathrm{aPb} \\
2009\end{array}$ & $\begin{array}{c}\% \\
\text { change }\end{array}$ & $\begin{array}{c}\mathrm{aPa} \\
1999\end{array}$ & $\begin{array}{c}\mathrm{aPa} \\
2009\end{array}$ & $\begin{array}{c}\% \\
\text { change }\end{array}$ & $\begin{array}{l}\text { DEL } \\
1999\end{array}$ & $\begin{array}{l}\text { DEL } \\
2009\end{array}$ & $\begin{array}{c}\% \\
\text { change }\end{array}$ \\
\hline $\begin{array}{l}\text { unemployment } \\
\text { rate }\end{array}$ & 12,1 & 11,0 & 0,213 & 0,082 & -62 & 0,872 & 0,886 & 2 & 0,128 & 0,114 & -11 & 0,285 & 0,274 & -4 \\
\hline farmers & 0,0 & 0,1 & 0,396 & 0,276 & -30 & 0,881 & 0,999 & 13 & 0,119 & 0,001 & -99 & 0,374 & 0,214 & -43 \\
\hline $\begin{array}{l}\text { craftsmen, } \\
\text { shopkeepers, } \\
\text { managers }\end{array}$ & 5,9 & 4,7 & 0,107 & 0,116 & 8 & 0,999 & 0,949 & -5 & 0,001 & 0,051 & 9523 & 0,174 & 0,179 & 3 \\
\hline $\begin{array}{c}\text { executives, } \\
\text { senior intellectual } \\
\text { workers }\end{array}$ & 34,8 & 42,2 & 0,103 & 0,076 & -27 & 0,936 & 0,565 & -40 & 0,064 & 0,435 & 585 & 0,206 & 0,214 & 3 \\
\hline $\begin{array}{l}\text { intermediary } \\
\text { professions }\end{array}$ & 23,1 & 23,3 & 0,042 & 0,040 & -4 & 0,632 & 0,764 & 21 & 0,368 & 0,236 & -36 & 0,249 & 0,250 & 1 \\
\hline employees & 24,5 & 20,8 & 0,063 & 0,071 & 13 & 0,766 & 0,786 & 3 & 0,234 & 0,214 & -9 & 0,250 & 0,259 & 4 \\
\hline $\begin{array}{l}\text { blue-collar } \\
\text { workers }\end{array}$ & 10,4 & 7,9 & 0,171 & 0,158 & -7 & 0,750 & 0,910 & 21 & 0,250 & 0,090 & -64 & 0,343 & 0,327 & -5 \\
\hline immigrants & n.a. & 20,3 & n.a. & 0,057 & & n.a. & 0,793 & & n.a. & 0,207 & & n.a. & 0,238 & \\
\hline foreigners & n.a. & 15,0 & n.a. & 0,066 & & n.a. & 0,846 & & n.a. & 0,154 & & n.a. & 0,239 & \\
\hline
\end{tabular}

Source: Self-elaborated after : INSEE 2012 


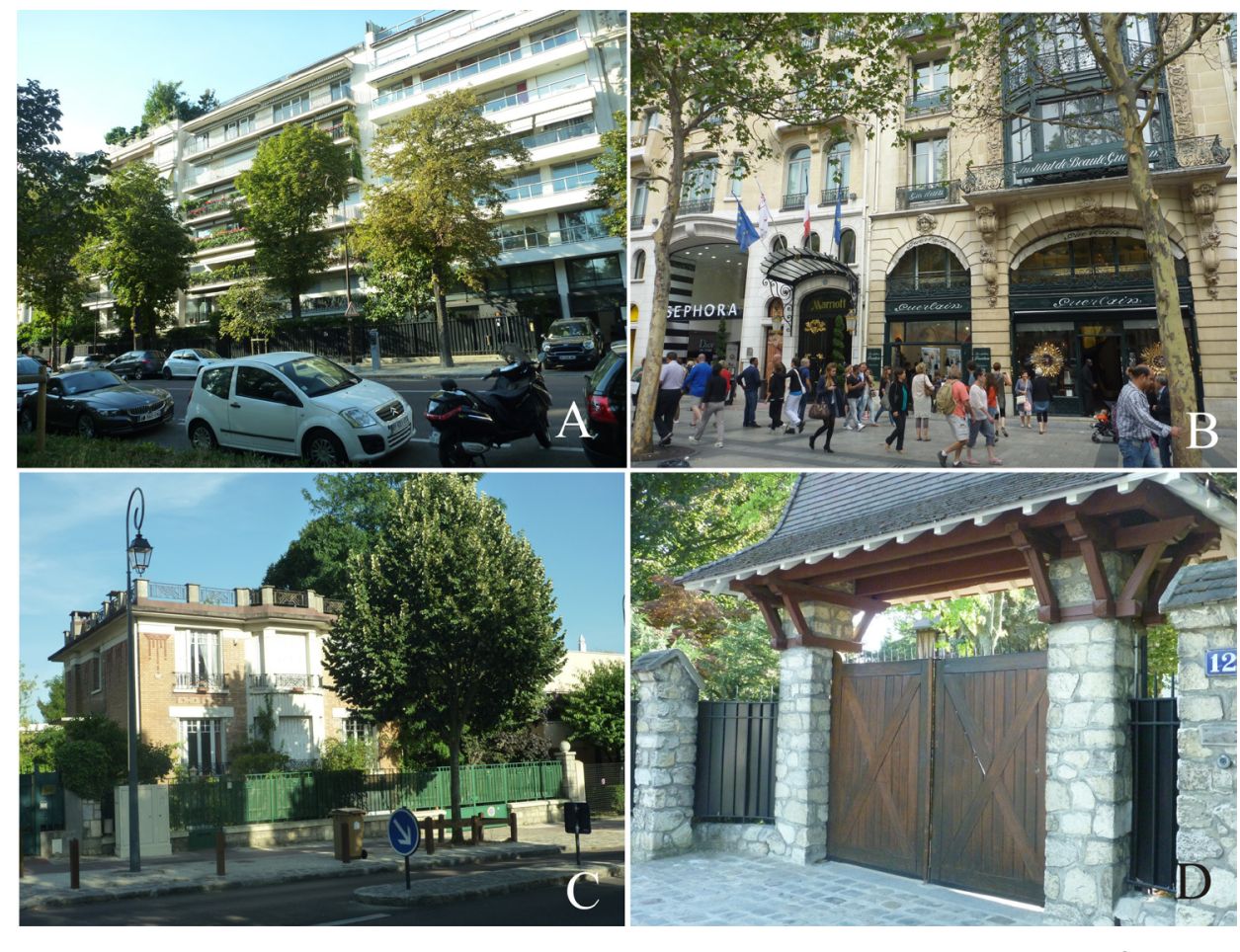

(phot.: A. Grzegorczyk)

Fig.1. The beaux quartiers: A - apartments facing Bois de Boulogne in Neuilly-sur-Seine, B - boulevardisation of the Champs Élysées, $C-$ a villa in Sceaux, $D$ - the gate of a villa in Sceaux

prices, it attracted La Défence investment, which enabled the completion of the prestigious Paris axis extending from the Arc $\mathrm{du}$ Carrousel. The central eminent districts are thus exposed to competition between residential and business functions, which is one of the reasons for the depopulation of Paris; the population of the VIIIth arrondisement decreased by half between 1954 and 1990 and was replaced by commuters and tourists (Jałowiecki 2010 after Pinçon 1996). This process is called boulevardisation ${ }^{10}$ (fig. 1B). The centrifugal movement of offices seen in Paris from the end of the 19th Century caused the outward migration of the population.

The Sceaux commune in the southern suburbs is an example of a prestigious town, further from the city centre; inhabited by the elite, it is also located in an attractive environment, near the Parc de Sceaux. Some villas are protected by high fences, which have a decorative function but to some extent also isolate their inhabitants (fig. 1C, 1D). The town has a cosy character and the park plays an important role in providing public space with alleys for jogging and other sports, where exhibitions and other community events take place.

The beaux quartiers inhabitants constitute mainly the French majority population with no immigration background or those originating from other European countries (Safi 2009). Their social structure and individual histories remain very similar - from education and career path, to household structure, family roles and leisure activities; hence they share a similar destiny, which differs a lot from that of other groups (see more: Rhein 1998, Maurin 2004).

The XIIIth arrondisement was chosen to present the rather heterogeneous character of certain Paris districts. There are apartment houses from different periods, HBM and HLM housing estates of different quality (fig. 2A, 2B) and "China town" runs

${ }^{10}$ The name of the process of Paris renovation conducted between 1852 and 1870 , from George Haussmann's urban concept. along Avenue de Choisy and Avenue d'Ivry. Contrary to its name, this area gathers a pan-Asian community, which is not numerous but very concentrated in Paris ${ }^{11}$. Not only Asian restaurants but also travel, insurance and real estate agencies, supermarkets, clothes shops etc. can be found in the vicinity (fig. 2C, 2D). That is, the service supply is differentiated. However, in middle class areas, foreigners are not numerous and the majority of them originate from Spain, Italy and Portugal. Median districts, mainly those of north-western Paris, underwent huge changes connected to investment in La Défense; well-off households replaced modest or poor households, the price of one-family dwellings increased and social polarisation between the rich living in such houses and the poor living in social housing increased (Rhein 1998).

The eastern and northern areas of Paris originally had an industrial character, with the spacious railway areas of the Gare du Nord and Gare de l'Est, and intersected by a system of canals. Their social characteristics have generally not evolved a great deal, yet their spatial pattern indicates a withdrawal process (Rhein 1998). Two districts were chosen to present the processes of this part of the metropolitan region. Belleville is an example of a traditional labour district divided into a lower and poorer part, and a higher, wealthier one. It has been widely transformed and the renovation programme introduced in 1950 is still in progress. Between 1954 and 1969, 20\% of the total housing stock, including flats for sale and HLM premises, was demolished. As a consequence, the spatial, social and ethnic character of the district changed. New buildings were disconnected from the urban fabric and between 1954 and 1990 the percentage of bluecollar workers decreased from $51 \%$ to $25 \%$ (Jałowiecki 2010). In addition, the number of immigrants doubled as they inhabited abandoned and degraded housing in the district's lower part.

$\overline{11 T h e y ~ a l s o ~ i n h a b i t ~ t h e ~ X I X t h ~ a n d ~ t h e ~ X X t h ~ a r r o n d i s e m e n t s ~(S a f i ~ 2009) . ~}$ 


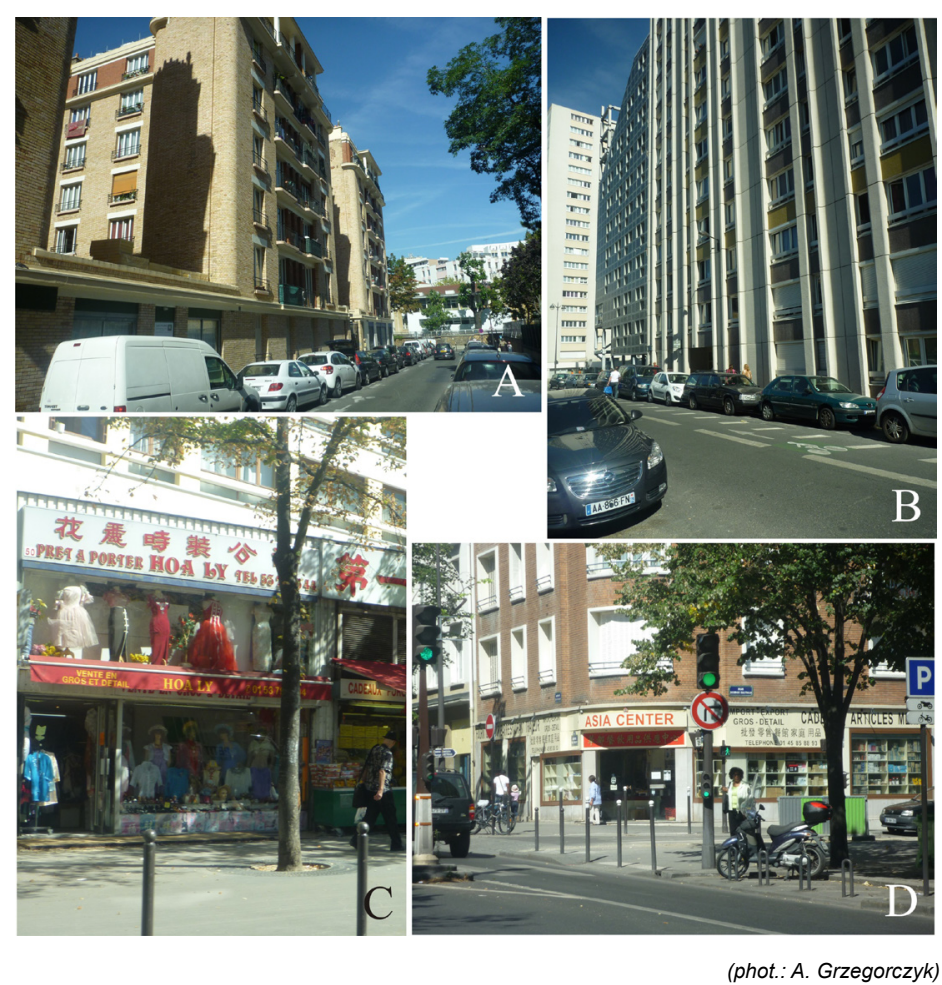

Fig. 2. The heterogeneous character of XIIt ${ }^{\text {th }}$ arrondisement : $A$ - better quality council housing, $B$ - worse quality council housing (HLM), $C$ - clothes shop in "China town », D- a supermarket in "China town »

The other newcomers constituted mainly public sector and mass media employees, academics and artists, and represented two approaches towards their neighbourhood: the 'multiculturalists' were against new demolition and supported the current individualistic character of the area, and the 'grafted/implanted' did not participate in the local social life.

The St. Denis commune is also traditionally inhabited by the working class; it has poor environmental conditions and is negatively viewed. With the initiative of its communist party authorities, a wide range of renovation programmes were conducted. Afterwards, the mixing of social housing inhabitants was supervised according to the following criteria: household income, number of children, age of inhabitants, length of living in the district, length of waiting for accommodation and the "one for one" principle, i.e. foreigners were replaced by foreigners (Jałowiecki 2010 after Vieillard Baron 1998). Although the authorities succeeded in attracting representatives of the well-educated with a cultural capital (but not of the affluent society), their rate of leaving the area for better locations is high. According to É. Maurin (2004), it is the threat of sharing a common fate with those living in "poor districts", rather than the social housing policy, that influences the homogeneity of such districts. Thus, St. Denis still has a particular immigrant character, where a significant part of the community is constituted by the AMT groups. In the central part of the town, close to the cathedral, a bazaar is located, selling such goods as traditional Muslim clothes and Islamic books (fig. 3A, 3B); further along can be found the Souk de St. Denis and shop windows with traditional women's clothes, all contributing to the immigrant feel of the place. The housing stock of the districts described is rather old and was hit by the de-industrialisation process. The further north-eastern peripheries are characterised by newer housing stock (mostly constituting HLM), built between the 1950s and the 1980s (fig. 3C).

\section{Conclusions}

The aim of the article was to present social and ethnic segregation in the Paris metropolitan area at the turn of the $21^{\text {st }}$ Century. The analysis was conducted for the communes of the l̂lede-France region and the city of Paris, between 1999 and 2009, and the segregation phenomenon was measured using data for socio-professional categories, and the number of immigrants and foreigners. Five indices were calculated showing different segregation dimensions: evenness, exposure, concentration and geographical localisation. The analysis revealed greater social segregation across the entire Paris metropolitan area than in the city itself. In Île-de-France, executives and senior intellectual workers are the most segregated of the different socio-professional categories, as shown by dissimilarity, isolation, concentration and localisation indices. The high segregation of foreigners is indicated by three indices (dissimilarity, concentration and localisation), by two indices for immigrants (dissimilarity and concentration) and two indices for blue-collar workers (dissimilarity and localisation). The lowest segregation, that of the intermediary professions, is presented by two of the calculated indicators (dissimilarity and localisation). In the city of Paris, the high segregation of bluecollar workers (dissimilarity, concentration and localisation) and the low segregation of intermediary professions (dissimilarity, exposure and localisation) were proved by three indices and the high segregation of the unemployed (concentration and localisation), executives and senior intellectual workers (exposure and localisation), and craftsmen, shopkeepers and managers (dissimilarity and localisation) calculated by two indices. Exposure indices appeared to be difficult to interpret because of the method's limitations. The pattern described revealed similarities to previous findings from analyses of earlier periods: the upper-class is the most isolated, followed by foreigners and the lower-class. 


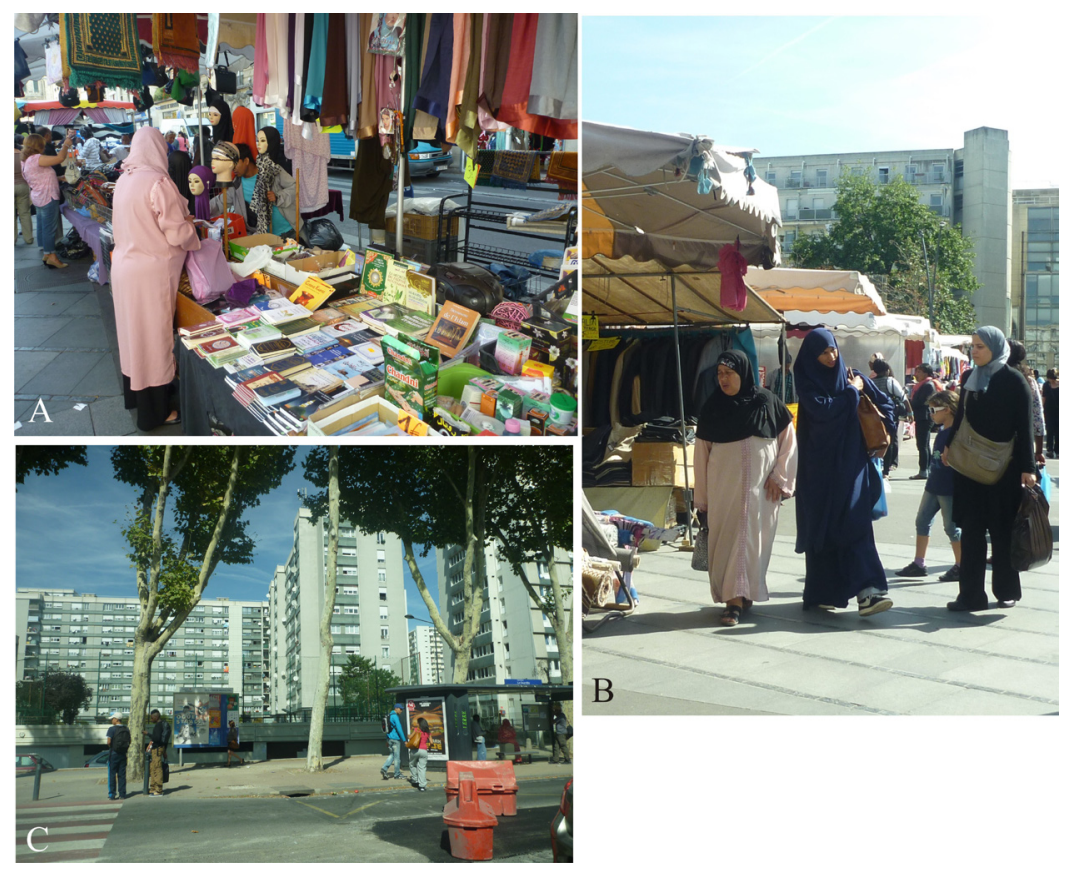

(phot.: A. Grzegorczyk)

Fig. 3. St. Denis: A, B - the central market place; C - social housing estates (HLM)

The continuity of the described tendencies proves Paris' spatial inertia, which is linked to the city's history and traditions. There is still a distinct division into homogenous areas in the prestigious and affluent western districts and the impoverished immigrant north-eastern districts. Other areas remain more heterogeneous. Despite a rather stable socio-spatial division across the whole area, tendencies to replace heterogeneous districts with more affluent ones or poor districts with more mixed ones can be observed. Moreover, the character of particular districts - their locational function, architecture and urban concept - reflects their socio-spatial development.

Finally, it can be stated that autosegragation factors play an importantrole in the Paris metropolitan area, where existing housing classes, location of prestigious schools, as well as the desire to live among the same social group, seem to be interconnected. Among the affluent, mutual support (e.g. education and career paths) and "attack" facilitation (e.g. local government elections) seem to be the most important autosegregation functions. For immigrants, mutual support and cultural preservation might also be important autosegregation functions; however, they are also hit by the segregation phenomenon - the distribution of immigrants of different origin reflects their socio-economic status. Therefore, there are ethnic enclaves, sometimes called ghettoes, and enclaves of poverty and affluence, the latter sometimes gated (e.g. Villa Montmorency, described above) and whose important features are a common lifestyle and community prestige rather than safety. Although these extremes are the most visible, it should be underlined that the middle class population and heterogeneous areas constitute an important socio-spatial part of Île-de-France. However, both social and spatial tendencies reveal the growing importance of a metropolitan class in the region.

\section{Acknowledgements}

The project and the article publication are financed by the University of Warsaw, Faculty of Geography and Regional Studies; grant number: 501/86-DSM-102800.
Appendix: Formulas of segregation indices

$$
\begin{aligned}
& \text { 1. Evenness - the dissimilarity index } \\
& I D=\frac{1}{2} \sum_{i=1}^{n}\left|\frac{x_{i}}{X}-\frac{y_{i}}{Y}\right| ; \quad I D \in\langle 0,1\rangle
\end{aligned}
$$

where $x_{i}$ and $y_{i}$ - the number of members in analysed groups in $i$ area unit, $X$ and $Y$ - the total population of the groups in the whole city subdivided into $n$ area units.

$$
\begin{aligned}
& \text { 2. Exposure } \\
& \text { - the interaction index } \\
& { }_{x} P_{y}=\sum_{i=1}^{n} \frac{x_{i}}{X} \times \frac{y_{i}}{t_{i}} ; \quad \in<0,1>
\end{aligned}
$$

where $t_{i}-$ the total population in $i$ area unit.

\section{- the isolation index}

$$
{ }_{x} P_{x}=\sum_{i=1}^{n} \frac{x_{i}}{X} \times \frac{x_{i}}{t_{i}} ;{ }_{x} P_{x} \in<0,1>
$$

\section{Concentration - delta}

$$
D E L=\frac{1}{2} \sum_{i=1}^{n}\left|\frac{x_{i}}{X}-\frac{a_{i}}{A}\right| ; D E L \in\langle 0,1\rangle
$$

where $a_{i}$ - the land area of $i$ area unit, $A$ - the total land area of the city.

\section{Localisation - the modified localisation index}

$L Q_{p}=\frac{{ }_{k} x_{i} / y_{i}{ }^{\prime}}{{ }_{k} X / Y^{\prime}} ; \quad L Q_{p} \geq 0$

where ${ }_{k} x_{i}-$ total population in $k$ group and in $i$ area unit, $y_{i}{ }^{\prime}-$ total population in $i$ area unit decreased by $k$ group population, ${ }_{k} X-$ total population in $k$ group in the whole city, $Y^{\prime}-$ city population decreased by $k$ group population in the city. 
Bidoux, P-E \& Virot, P 2011, 'L'accès à l'emploi et au logement s'améliore pour les immigrés à Paris mais les inégalités et les discriminations persistent', lle-de-France à la page, no. 376. Available from: <www.insee.fr>. [1 May 2012].

Blakley, EJ \& Snyder, MG 1997, Fortress America. Gated Communities in the United States, Brookings Institution Press, Washington, DC.

Castells, M 2000, End of Millennium, Blackwell Publishers, Oxford, pp. 70-170

Claval, P 1981, La logique des villes. Essai d'urbanologie, LITEC, Paris.

Grzegorczyk, A 2012, 'Socio-spatial diversity of Marseille at the turn of the $21^{\text {st }}$ century', Bulletin of Geography, no. 17, pp. 45-55. Available from: <versita.metapress.com>. [1 July 2012]

Guérois, M \& Paulus, F 2002, 'Commune centre, agglomération, aire urbaine : qeulle pertinence pour l'étude des villes ?', Cybergeo : Revue européenne de Géographie, no 212.

INSEE, Available from: <www.insee.fr>. [1 July 2012].

Jałowiecki, B 2010, Miasto i przestrzeń w perspektywie socjologicznej, Wydawnictwo Naukowe SCHOLAR, Warszawa, pp. 246-262

Knox, P \& Pinch, S 2000, Urban Social Geography, Prentice Hall, England, pp. 227-247

La Cité interdite 2008, Le Point, Available from: <www. lepoint.fr/actualites-societe/2008-07-10/la-citeinterdite/920/0/259536>. [10 September 2012].

Lajoie, G 1998, 'La ségrégation des populations urbaines de 1982 à 1990', in : Données urbaines, eds D Pumain, Anthropos, Paris, pp. 191-206.

Massey, DS \& Denton, NA 1988, 'The Dimensions of Residential Segregation', Social Forces, vol. 67, no. 2, pp. 281-315, Available from: <www.jstor.org>. [1 May 2012].
Maurin, É 2004, Le ghetto français. Enquête sur le séparatisme social, La République des Idées, Seuil, France

Maxwell, R 2010, 'Political Participation in France among NonEuropean-Origin Migrants: Segregation or Integration', Journal of Ethnic and Migration Studies, vol. 36, no. 3, March 2010, pp. 425-443.

Mitchell, K 2011, 'Marseille's Not for Burning: Comparative Networks of Integration and Exclusion in Two French Cities', Annals of the Association of American Geographers, vol. 101, no. 2, pp. 404-423.

Pan Ké Shon, JL 2011, 'La ségrégation des immigrés en France: état des lieux', Population - Sociétés, no 477, Available from:<www.insee.fr>. [1 May 2012].

Préteceille, E 2006, 'La ségrégation social a-t-elle augmenté ? La métropole parisienne antre polarisation et mixité', Sociétés contemporaines, 2006/2, no 62, pp. 69-93, Available from: $<$ www.cairn.info>. [1 June 2012].

Rhein, C 1998, 'Globalisation, Social Change and Minorities in Metropolitan Paris : The Emergence of New Class Patterns', Urban Studies, vol. 35, no. 3, pp. 429-447.

Safi, M 2009, 'La dimension spatial de l'intégration : évolution de la ségrégation des population immigrées en France entre 1968 et 1999', Revue française de sociologie, 2009/3, vol. 50, pp. 521-552, Available from: <www.cairn.ifno>. [1 June 2012].

Sassen, S 1991, The Global City. New York, London, Tokyo, Princeton University Press, Princeton.

Trajectoires et origines enquets (Trajectories and origines survey). Available from: <teo.site.ined.fr>. [1 July 2012].

Węcławowicz, G 2007, Geografia społeczna miast, Wydawnictwo Naukowe PWN, Warszawa, pp. 116-128. 